\title{
Genetic and molecular bases of peroxisome biogenesis disorders
}

\author{
Yasuyuki Suzuki, $M D, P h D^{1,2}$, Nobuyuki Shimozawa, $M D, P h D^{2}$, Tadao Orii, $M D, P h D^{3}$, \\ Toshiro Tsukamoto, $\mathrm{MD}, \mathrm{PhD}^{4}$, Takashi Osumi, $\mathrm{PhD}^{4}$, Yukio Fujiki, $\mathrm{PhD}^{5}$, and Naomi Kondo, $\mathrm{MD}, \mathrm{PhD}^{2}$
}

Peroxisomes are ubiquitous organelles present in almost all eukaryotic cells and have a number of important metabolic pathways. They were discovered in 1954 and named peroxisomes in $1965 .{ }^{1}$ Peroxisomes have their own system of fatty acid $\beta$-oxidation. ${ }^{2,3}$ This system catalyzes a wide variety of substrates, including very long chain fatty acids (VLCFAs) such as lignoceric acid (C24:0) and cerotic acid (C26:0), bile acid intermediates such as trihydroxycholestanoic acid (THCA) and dihydroxycholestanoic acid (DHCA), and branched chain fatty acids like pristanic acid and phytanic acid. Plasmalogens are a special group of phospholipids, which are an important constituent of the brain and require peroxisomes for their synthesis. ${ }^{4}$ Glyoxylate is a precursor of oxalate and is metabolized to glycine by alanine-glyoxylate aminotransferase. ${ }^{5}$ Peroxisomes are also considered to play roles in the synthesis of docosahexaenoic acid (DHA) ${ }^{6}$ and cholesterol. ${ }^{7}$ Catalase, a marker enzyme of peroxisomal matrix, plays an important role in the degradation of hydrogen peroxide. ${ }^{1}$

Inborn errors of peroxisomes are classified into two categories: peroxisome biogenesis disorders (PBDs) and single enzyme deficiencies (Table 1). Generalized PBDs include Zellweger's cerebro-hepato-renal syndrome $(\mathrm{ZS}),{ }^{8}$ the most severe phenotype; neonatal adrenoleukodystrophy (NALD), ${ }^{9}$ the intermediate; and infantile Refsum disease (IRD), ${ }^{10}$ the least severe phenotype. Rhizomelic chondrodysplasia punctata $(\mathrm{RCDP})^{11}$ is a partial PBD. Deficiency of peroxisomes in ZS was first identified in 1973,12 then the accumulation of VLCFAs was first reported in $1982 .{ }^{13}$ These PBDs are caused by a defect in PEX genes, which encode peroxins, proteins necessary for peroxisome biogenesis and import of peroxisomal proteins.

\section{CLINICAL, PATHOLOGICAL, AND BIOCHEMICAL FINDINGS OF PBDs}

Zellweger syndrome was first reported in 1964 as an autosomal recessive disease with multiple congenital malformations. ${ }^{8}$ Patients with ZS manifest severe hypotonia from the neonatal

\footnotetext{
From the ${ }^{1}$ Medical Education Development Center and ${ }^{2}$ Department of Pediatrics, Gifu University School of Medicine, Gifu, ${ }^{3}$ Faculty of Human Welfare, Chubu Gakuin University, Seki; ${ }^{4}$ Department of Life Science, Himeji Institute of Technology, Hyogo; and ${ }^{5}$ Department of Biology, Graduate School of Science, Kyushu University, Fukuoka, Japan.

Yasuyuki Suzuki, MD, Medical Education Development Center, Gifu University School of Medicine, Tsukasa-machi 40, Gifu 500-8705, Japan.

Received: November 21, 2000.

Accepted: June 19, 2001
}

period, psychomotor retardation, facial dysmorphism such as high forehead and large fontanelle, hepatomegaly with prolonged jaundice and liver dysfunctions, calcific stippling of the patella, renal cortical microcysts, retinal degeneration, and congenital heart disease, and usually die during the early infantile period. Neonatal adrenoleukodystrophy is a phenotype with less severe clinical findings. Patients with NALD gradually develop, but then regression occurs, and patients usually die during the late infantile period. Infantile Refsum disease is characterized by hearing impairment, retinal degeneration, and mild psychomotor retardation, and patients usually survive longer. ${ }^{14}$

Defective neuronal migration is the main pathological finding in ZS. ${ }^{15}$ Polymicrogyria, pachygyria, heterotopia of cerebral neurons and Purkinje cells in the cerebellum, dysplasia of olivary complex, and hypomyelination are also characteristic findings. Architecture of cerebral cortex is disorganized and abnormally thick. The cerebellar Purkinje layer is irregular, and heterotopic Purkinje cells are seen in the cerebellar white matter. The olivary nucleus is thick and poorly convoluted. The NALD brain shows demyelination. Lamellar inclusion bodies, which consist of cholesterol esters of VLCFAs, are observed in macrophages and adrenocortical cells.

Biochemical abnormalities of PBDs are as follows: accumulation of VLCFAs (C24:0, C25:0, C26:0), intermediate substances of bile acid synthesis (THCA, DHCA) and branched chain fatty acid (pristanic and phytanic acid); deficiency of plasmalogens and DHA; and absent or severely decreased peroxisomes. All phenotypes of PBDs show these findings; however, patients with milder phenotypes tend to have less severe abnormalities. ${ }^{14}$ Peroxisomes are morphologically absent or severely reduced in hepatocytes (Fig. 1C) or fibroblasts (Fig. 1D). Peroxisomal ghosts, which are remnant membranous structures, can be detected in many PBD cell lines when the cells are stained with anti-PMP70, ${ }^{16}$ a major peroxisomal membrane protein. However, some PBD cell lines lack ghosts, ${ }^{17}$ which suggests that biogenesis of peroxisomal membrane itself is disordered. Peroxisomes also show another interesting phenomenon: temperature sensitivity (ts) of peroxisome biogenesis. ${ }^{18}$ That is the biogenesis of peroxisomes and biochemical defects in the cells from patients with milder phenotypes such as NALD and IRD are restored at the lower temperature, $30^{\circ} \mathrm{C}$, whereas the biogenesis is not restored in the severe Zellweger cells at $30^{\circ} \mathrm{C}$. This phenomenon is useful for predicting the clinical severity and for investigating peroxisomal biogenesis. 
Table 1

Peroxisomal disorders

A. Peroxisome biogenesis disorders (PBDs)

1. Zellweger syndrome (ZS)

2. Neonatal adrenoleukodystrophy (NALD)

3. Infantile Refsum disease (IRD)

4. Rhizomelic type chondrodysplasia punctata (RCDP)

5. Zellweger-like syndrome

B. Isolated enzyme deficiencies

1. Adrenoleukodystrophy (ALD)

2. Acyl-CoA oxidase deficiency

3. D-Bifunctional protein deficiency

4. 3-Ketoacyl-CoA thiolase deficiency

5. Dihydroxyacetone phosphate (DHAP) acyltransferase deficiency

6. Alkyl-DHAP synthase deficiency

7. Refsum disease (phytanoyl-CoA hydroxylase deficiency)

8. Alpha-methylacyl-CoA racemase deficiency

9. Acatalasemia

10. Hyperoxaluria type I (alanine glyoxylate aminotransferase deficiency)

11. Mavalonate kinase deficiency

12. Glutaric aciduria type 3 (glutaryl-CoA oxidase deficiency)

A
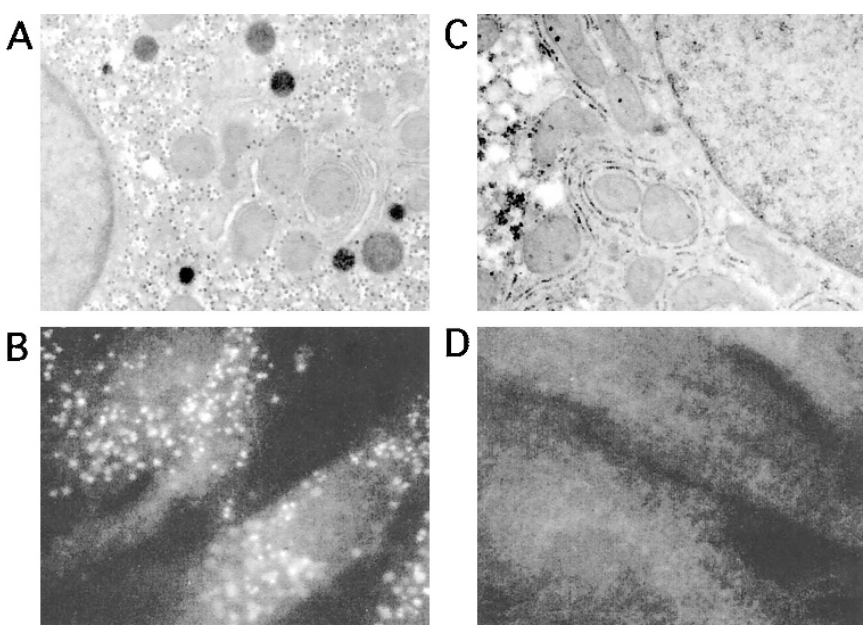

Fig. 1 Electron micrograph and immunofluorescence staining of peroxisomes. A: Control hepatocytes (electron micrograph with diaminobenzidine staining). B: Control fibroblasts (immunofluorescence staining with anticatalase). C: Zellweger hepatocytes (electron micrograph with diaminobenzidine staining). D: Zellweger fibroblasts (immunofluorescence staining with anticatalase).

\section{GENETIC HETEROGENEITY AND PATHOGENIC GENES FOR PBDs}

Genetic heterogeneity of PBDs was first identified in $1988 .{ }^{19}$ Biochemical defects were restored when some pairs of PBD cell lines were fused. ${ }^{20}$ In 1992, we identified five complementation groups using immunofluorescence staining of catalase as a marker. ${ }^{21}$ If pathogenic genes are different, peroxisomes will be formed in multinuclear cells a few days after cell fusion. An international collaborative study has led to the identification of 12 groups at present (Table 2). ${ }^{17} \mathrm{ZS}, \mathrm{NALD}$, and IRD belong to 11 groups. RCDP is genetically heterogeneous and belongs to one PBD group and the single enzyme deficiency group. Patients with dihydroxyacetone phosphate (DHAP) acyltransferase deficiency and alkyl-DHAP synthase deficiency also manifest RCDP phenotype. Group 1(E) is the largest group, and more than half the number of patients belong to this group. Groups D, G, and J lack peroxisomal ghosts, and these groups contain only ZS, the most severe phenotype. At present, 11 of the genes associated with the different complementation groups have been identified. These genes are called PEX genes, and the gene products are called Pexp (peroxins).

The first isolated mammalian PEX gene is PEX2, which was first called peroxisome assembly factor-1 (PAF1). ${ }^{22}$ This gene was cloned by means of functional complementation cloning using peroxisome-deficient Chinese hamster ovary $(\mathrm{CHO})$ cells. Expression library was transfected into these $\mathrm{CHO}$ mutants, cells with restored peroxisome biogenesis were selected, and the cDNA was recovered from these cells. Pex2p is a 35$\mathrm{kDa}$ peroxisomal membrane protein and has two membrane spanning regions and a RING finger motif. In 1992, we clarified that PEX2 restored biogenesis of peroxisomes in fibroblasts from a ZS patient who belonged to complementation group F. ${ }^{23}$ This patient carried a homozygous nonsense mutation R119Ter. A frameshift mutation del 550C, which destroys the second membrane spanning region, is associated with severe ZS, whereas another frameshift mutation del $642 \mathrm{G}$, which destroys only the RING finger motif, is found in the milder IRD phenotype. ${ }^{24} \mathrm{~A}$ missense mutation E55K, which was identified in a IRD patient, proved to be a ts mutation. ${ }^{18}$ The second gene identified in PBD patients is PEX5.25 This gene was cloned by expressed sequence tag (EST)-homology search using a human database and information on the yeast PEX gene. Pex5p is a cytosolic receptor for peroxisomal targeting signal (PTS)-1. A Zellweger patient who belonged to Group 2 had a nonsense mutation R390Ter, and an NALD patient had a missense mutation. The PTS-1 receptor binds tightly to the PTS-1 motif of acyl-CoA oxidase, Ser-Lys-Leu (SKL), whereas the binding potential to Ala-Lys-Leu (AKL) in D-bifunctional protein or LysAla-Asn-Leu (KANL) in catalase is weaker. ${ }^{26}$ PEX6, the gene for group $\mathrm{C} P B D$, was also cloned using the functional complementation method. ${ }^{27}$ Pex6p belongs to the group of AAA-proteins and is considered to interact with Pexlp. ${ }^{28} \mathrm{~A}$ splice mutation and a one base insertion were identified in ZS patients. ${ }^{29}$ $P E X 12$ encodes a peroxisomal integral membrane protein with RING finger motif. One ZS patient who belonged to Group 3 $\mathrm{PBD}$ had a frameshift mutation. ${ }^{30}$ Pex $12 \mathrm{p}$ is considered to play roles in protein import downstream to PTS1- or PTS2- receptor docking event. ${ }^{31}$ PEX1 is the pathogenic gene for Group 1 (E), the largest group of PBDs. ${ }^{32,33} \mathrm{~A}$ common one-base insertion 2097insT was found in severe ZS patients. Another common missense mutation G843D was found among patients with milder phenotypes, and it was a ts mutation. ${ }^{34}$ 
Table 2

Complementation groups, genes for PBDs, and ts mutations

\begin{tabular}{|c|c|c|c|c|c|c|}
\hline Gifu & KKI & Phenotype & Ghosts & Gene & Mapping & ts Mutations \\
\hline A & 8 & ZS, NALD, IRD & + & & & \\
\hline B & 7 & ZS, NALD & + & PEX10 & & \\
\hline C & 4 & ZS, NALD & + & PEX6 & $6 \mathrm{p} 21.1$ & L57P \\
\hline D & 9 & ZS & - & PEX16 & & \\
\hline E & 1 & ZS, NALD, IRD & + & PEX1 & $7 \mathrm{q} 21-22$ & G843D \\
\hline $\mathrm{F}$ & 10 & ZS, IRD & + & PEX2 & $8 \mathrm{q} 21.1$ & E55K \\
\hline G & & ZS & - & PEX3 & 6q23-24 & \\
\hline $\mathrm{H}$ & 13 & ZS, NALD & + & PEX13 & 2 & $\mathrm{I} 326 \mathrm{~T}$ \\
\hline \multirow[t]{3}{*}{$J$} & & ZS & - & PEX19 & 1 & \\
\hline & 2 & ZS, NALD & + & PEX5 & 12p13.3 & \\
\hline & 3 & ZS, NALD, IRD & + & PEX12 & & \\
\hline $\mathrm{R}$ & 11 & RCDP & & PEX7 & $6 \mathrm{q} 22-24$ & \\
\hline
\end{tabular}

Gifu, Gifu University School of Medicine (Japan); KKI, Kennedy Krieger Institute (USA).

PEX7, the gene for RCDP, was cloned by EST homology search by several investigators. ${ }^{35-37} \mathrm{Pex} 7 \mathrm{p}$ is a receptor for PTS-2 proteins such as 3-ketoacyl-CoA thiolase and alkyl-DHAP synthase. A common nonsense mutation L292Ter was shown to be caused by the founder effect. ${ }^{38}$ PEX10 is the gene for Group 7 PBD and encodes an integral membrane protein with a RING finger motif. ${ }^{39,40} \mathrm{Pex} 10 \mathrm{p}$ is considered to play roles in protein import downstream to PTS1- or PTS2- receptor docking event. ${ }^{31}$ PEX16 encodes a peroxisomal membrane protein and restores the localization of both peroxisomal membrane proteins and matrix enzymes in group D PBD. ${ }^{17} \mathrm{~A}$ ZS patient in group D had a nonsense mutation R176Ter. ${ }^{41}$ PEX19 is the gene for group J PBD, and it encodes a farnesylated protein with 299 amino acids. One base insertion 764insA was identified in a ZS patient. ${ }^{42}$ Pex19p is considered to interact with various peroxisomal membrane proteins and $\mathrm{ABC}$ half transporters such as PMP70 and ALD protein ${ }^{43,44}$ and is considered to be involved in the early stages of peroxisome biogenesis. PEX13 encodes a membrane protein which had a SH3 docking site with PTS1 receptor, and it restores the biogenesis of peroxisomes in group H PBD. ${ }^{45} \mathrm{~A} \mathrm{ZS}$ patient had a nonsense mutation W234Ter which completely destroyed the SH3 binding domain, and an NALD patient had a missense mutation I326T in the $\mathrm{SH} 3$ domain which causes the ts phenomenon. ${ }^{45}$ Pex13p is also required for the localization of Pex14p- and PTS-2dependent protein import. ${ }^{46} \mathrm{PEX} 3$ is the gene for group G PBD which lacks ghosts. ${ }^{47,48}$ By transfecting PEX3, both matrix enzymes and membrane proteins are localized into peroxisomes. Pex $3 p$ is considered to initiate membrane assembly. ${ }^{49}$

\section{MOLECULAR AND BIOCHEMICAL CORRELATION WITH THE PHENOTYPE}

Patients with milder phenotypes tend to have less severe biochemical abnormalities. ${ }^{50}$ The defects in plasmalogen synthesis and the degree of VLCFA accumulation in NALD are less severe than in Zellweger syndrome. A few residual peroxisomes could be detected in hepatocytes or in fibroblasts from patients with NALD or IRD. However, it is difficult to predict clinical severity or prognosis of a patient with PBDs solely on the basis of biochemical analysis. Molecular analysis of $P E X$ genes revealed that many of the patients with severe Zellweger syndrome had severe mutations, including nonsense mutations, frameshift mutations, and deletions, whereas many of NALD or IRD patients had missense mutations. ${ }^{23-25,29,30,32,33,35-42,45,48}$ There is also a relationship between severe phenotype and absence of ghosts. Defects of PEX3, PEX16, and PEX19 genes (group G, D and J) lead to absence of ghosts and severe Zellweger phenotypes. ${ }^{41,42,48}$ Severity of phenotypes also correlate with ts phenomenon. Many cell lines from patients with milder phenotypes showed ts phenotype. When the cells from mild phenotype are cultivated at $30^{\circ} \mathrm{C}$, peroxisomes are formed in almost all cells and the biochemical abnormalities are normalized. Mutation analyses revealed the presence of specific ts mutations. ${ }^{18,34,45,51}$ These are all missense mutations (Table 2).

\section{PATHOPHYSIOLOGY OF PBDs}

PEX gene products, peroxins, are encoded by nuclear genes. Several important functions of peroxins have been obtained from the investigations of PBDs (Fig. 2). Pex3p, Pex16p, and Pex19p are considered to play roles in the early stages of peroxisome biogenesis, membrane integrity and transport of various membrane proteins, including other peroxins and $\mathrm{ABC}$ half transporters. ${ }^{41,43,44,49}$ Pex $5 p$ and Pex7p, the specific receptors for PTS- 1 and PTS-2 proteins, are considered to bind PTS- 1 and PTS- 2 proteins, interact with Pexlp and Pex6p, and bind to the transport machinery in the membrane, followed by their recycling. ${ }^{25,35,36,37}$ Pex2p, Pex10p, and Pex12p, the integral membrane protein with a RING finger, are considered to form part of the transport machinery. 


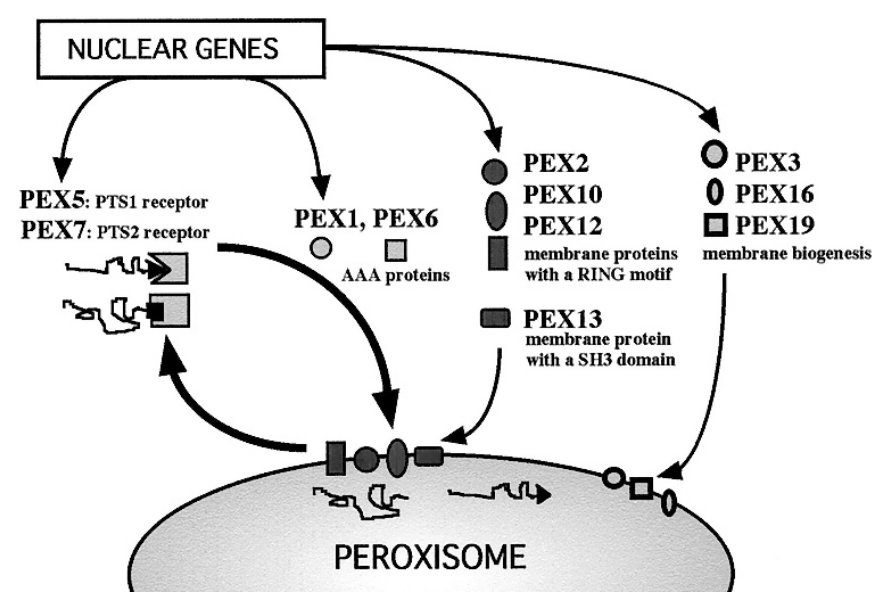

Fig. 2 Biogenesis of peroxisomes and functions of $P E X$ gene products.

Defects of these PEX genes cause the dysfunction of transport machinery and lead to mislocalization of multiple enzymes and metabolic dysfunctions: accumulation of VLCFA, bile acid intermediates, and phytanic and pristanic acid; deficiency of plasmalogens and DHA. Defects of $\beta$-oxidation system per se would play a major role in migration disorders and demyelination process, since isolated deficiencies of peroxisomal $\beta$-oxidation enzymes manifest these neuropathology. ${ }^{52}$ Deficiency of plasmalogen is considered to cause abnormal myelination and bone abnormalities, because DHAP-acyltransferase deficiency manifests these findings. ${ }^{53}$ Phytanic acid may lead to retinal degeneration and hearing impairment. Deficiency of DHA is considered to relate to brain and visual dysfunction and abnormal myelination. ${ }^{54,55}$

Although 11 human PEX genes have been identified, there are over 20 yeast PEX genes. Novel complementation groups and responsible genes may be elucidated in the near future. While considerable information on the $P E X$ genes has been obtained, precise structural and functional bases of pathophysiology of PBDs remains to be elucidated. Two mouse models for Zellweger syndrome have been generated by inactivating the murine PEX5 and PEX2 genes, respectively. ${ }^{56,57}$ PEX5-deficient mice exhibited the typical clinical, biochemical, and pathological abnormalities of ZS, including severe hypotonia and impaired neuronal migration. These model mice will provide important knowledge on mechanisms of pathological changes and peroxisome biogenesis.

\section{Acknowledgments}

The authors thank Dr. R.J.A. Wanders (Amsterdam University), Dr. H.W. Moser (Kennedy-Krieger Institute), Dr. B. Paton (Women's and Children's Hospital, North Adelaide), and Dr. G.T.N. Besley (Royal Manchester Children's Hospital) for their kind collaboration.

\section{References}

1. de Duve C, Baudhuin P. Peroxisomes (microbodies, and related particles). Physiol Rev 1966;46:323-357.
2. Lazarow PB, de Duve C. A fatty acyl-CoA oxidizing system in rat liver peroxisomes; enhancement by clofibrate, a hypolipidemic drug. Proc Natl Acad Sci USA 1976;73: 2043-2046.

3. Wanders RJ, van Grunsven EG, Jansen GA. Lipid metabolism in peroxisomes: enzymology, functions and dysfunctions of the fatty acid alpha- and beta-oxidation systems in humans. Biochem Soc Trans 2000;28:141-149.

4. Heymans HS, Schutgens RB, Tan R, van den Bosch H, Borst P. Severe plasmalogen deficiency in tissues of infants without peroxisomes (Zellweger syndrome). Nature 1983;306:69-70.

5. Danpure CJ. Variable peroxisomal and mitochondrial targeting of alanine: glyoxylate aminotransferase in mammalian evolution and disease. Bioessays 1997;19:317326.

6. Martinez M. Severe deficiency of docosahexaenoic acid in peroxisomal disorders: a defect of delta 4 desaturation? Neurology 1990;40:1292-1298.

7. Olivier LM, Krisans SK. Peroxisomal protein targeting and identification of peroxisomal targeting signals in cholesterol biosynthetic enzymes. Biochim Biophys Acta 2000;1529:89-102.

8. Bowen P, Lee CSN, Zellweger H, Lindenberg R. A familial syndrome of multiple congenital defects. Bull Johns Hopkins Hosp 1964;114:402-414.

9. Ulrich J, Herschkowitz N, Heitz P, Sigrist T, Baerlocher P. Adrenoleukodystrophy. Preliminary report of a connatal case. Light- and electron microscopical, immunohistochemical and biochemical findings. Acta Neuropathol 1978;43:77-83.

10. Scotto JM, Hadchouel M, Odievre M, Laudat MH, Saudubray JM, Dulac O, Beucler I, Beaune P. Infantile phytanic acid storage disease, a possible variant of Refsum's disease: three cases, including ultrastructural studies of the liver. J Inherit Metab Dis 1982;5:83-90.

11. Heymans HS, Oorthuys JW, Nelck G, Wanders RJ, Schutgens RB. Rhizomelic chondrodysplasia punctata: another peroxisomal disorder. N Engl J Med 1985;313:187188.

12. Goldfischer S, Moore CL, Johnson AB, Spiro AJ, Valsamis MP, Wisniewski HK, Ritch RH, Norton WT, Rapin I, Gartner LM. Peroxisomal and mitochondrial defects in the cerebro-hepato-renal syndrome. Science 1973;182:62-64.

13. Brown FR III, McAdams AJ, Cummins JW, Konkol R, Singh I, Moser AB, Moser HW. Cerebro-hepato-renal (Zellweger) syndrome and neonatal adrenoleukodystrophy: similarities in phenotype and accumulation of very long chain fatty acids. Johns Hopkins Med J 1982;151:344-351.

14. Lazarow PB, Moser HW. Disorders of peroxisome biogenesis. In: Scriver CR, Beau$\operatorname{det}$ AL, Sly WS, Valle D, editors. The metabolic and molecular bases of inherited disease. New York: McGraw-Hill, 1995:2287-2324.

15. Volpe JJ, Adams RD. Cerebro-hepato-renal syndrome of Zellweger: an inherited disorder of neuronal migration. Acta Neuropathol 1972;20:175-198.

16. Santos MJ, Imanaka T, Shio H, Small GM, Lazarow PB. Peroxisomal membrane ghosts in Zellweger syndrome -aberrant organelle assembly. Science 1988;239:15361538 .

17. Shimozawa N, Suzuki Y, Zhang Z, Imamura A, Kondo N, Kinoshita N, Fujiki Y, Tsukamoto T, Osumi T, Imanaka T, Orii T, Beemer F, Mooijer P, Dekker C, Wanders RJA. Genetic basis of peroxisome assembly mutants of humans, $\mathrm{CHO}$ cells and yeast: identification of a new complementation group of peroxisome biogenesis disorders, absent from peroxisomal membrane ghosts. Am J Hum Genet 1998;63: 1898-1903.

18. Imamura A, Tsukamoto T, Shimozawa N, Suzuki Y, Zhang Z, Imanaka T, Fujiki Y, Orii T, Kondo N, Osumi T. Temperature-sensitive phenotypes of peroxisome-assembly processes represent the milder forms of human peroxisome-biogenesis disorders. Am J Hum Genet 1998;62:1539-1543.

19. Brul S, Westerveld A, Strijland A, Wanders RJA, Schram AW, Heymans HSA, Schutgens RBH, Bosch Hvd, Tager JM. Genetic heterogeneity in the cerebrohepatorenal (Zellweger) syndrome and other inherited disorders with a generalized impairment of peroxisomal functions. J Clin Invest 1988;81:1710-1715.

20. Roscher AA, Hoefler S, Hoefler G, Paschke E, Paltauf F, Moser A, Moser H. Genetic and phenotypic heterogeneity in disorders of peroxisome biogenesis-a complementation study involving cell lines from 19 patients. Pediatr Res 1989;26:67-72.

21. Yajima S, Suzuki Y, Shimozawa N, Yamaguchi S, Orii T, Fujiki Y, Osumi T, Hashimoto T, Moser HW. Complementation study of peroxisome-deficient disorders by immunofluorescence staining and characterization of fused cells. Hum Genet 1992; 88:491-499.

22. Tsukamoto T, Miura S, Fujiki Y. Restoration by a $35 \mathrm{~K}$ membrane protein of peroxisome assembly in a peroxisome-deficient mammalian cell mutant. Nature 1991; 350:77-81.

23. Shimozawa N, Tsukamoto T, Suzuki Y, Orii T, Shirayoshi Y, Mori T, Fujiki Y. A human gene responsible for Zellweger syndrome that affects peroxisome assembly. Science 1992;255:1132-1134.

24. Shimozawa N, Zhang Z, Imamura A, Suzuki Y, Fujiki Y, Tsukamoto T, Osumi T, Aubourg P, Wanders RJA, Kondo N. Molecular mechanisms of detectable catalase- 


\section{Suzuki et al.}

containing particles, peroxisomes, in fibroblasts from a PEX2-defective patient. Biochem Biophys Res Commun 2000;268:31-35.

25. Dodt G, Braverman N, Wong C, Moser A, Moser HW, Watkins P, Valle D, Gould SJ. Mutations in the PTS1 receptor gene, PXR1, define complementation group 2 of the peroxisome biogenesis disorders. Nat Genet 1995;9:115-125.

26. Shimozawa N, Zhang Z, Suzuki Y, Imamura A, Tsukamoto T, Osumi T, Fujiki Y, Orii T, Barth PG, Wanders RJA, Kondo N. Functional heterogeneity of C-terminal peroxisome targeting signal 1 in PEX5-defective patients. Biochem Biophys Res Commun 1999;262:504-508.

27. Tsukamoto T, Miura S, Nakai T, Yokota S, Shimozawa N, Suzuki Y, Orii T, Fujiki Y, Sakai F, Bogaki A, Yasumo H, Osumi T. Peroxisome assembly factor-2: a putative ATPase cloned by functional complementation on a peroxisome-deficient mammalian cell mutant. Nat Genet 1995;11:395-401.

28. Geisbrecht BV, Collins CS, Reuber BE, Gould SJ. Disruption of a PEX1-PEX6 interaction is the most common cause of the neurologic disorders Zellweger syndrome, neonatal adrenoleukodystrophy, and infantile Refsum disease. Proc Natl Acad Sci USA 1998;95:8630-8635.

29. Fukuda S, Shimozawa N, Suzuki Y, Zhang Z, Tomatsu S, Tsukamoto T, Hashiguchi N, Osumi T, Masuno M, Imaizumi K, Kuroki Y, Fujiki Y, Orii T, Kondo N. Human peroxisome assembly factor-2 (PAF-2): a gene responsible for group $\mathrm{C}$ peroxisome biogenesis disorder in humans. Am J Hum Genet 1996;59:1210-1220.

30. Chang CC, Lee WH, Moser H, Valle D, Gould SJ. Isolation of the human PEX12 gene, mutated in group 3 of the peroxisome biogenesis disorders. Nat Genet 1997; 15:385-388.

31. Chang CC, Warren DS, Sacksteder KA, Gould SJ. PEX12 interacts with PEX5 and $P E X 10$ and acts downstream of receptor docking in peroxisomal matrix protein import. J Cell Biol 1999;147:761-774.

32. Reuber BE, Germain LE, Collins CS, Morrell JC, Ameritunga R, Moser HW, Valle D, Gould SJ. Mutations in PEX1 are the most common cause of peroxisome biogenesis disorders. Nat Genet 1997;17:445-448.

33. Portsteffen H, Beyer A, Becker E, Epplen C, Pawlak A, Kunau WH, Dodt G. Human $P E X 1$ is mutated in complementation group 1 of the peroxisome biogenesis disorders. Nat Genet 199717;449-452.

34. Imamura A, Tamura S, Shimozawa N, Suzuki Y, Zhang Z, Tsukamoto T, Orii T, Kondo N, Osumi T, Fujiki Y. Temperature-sensitive mutation in PEX1 moderates the phenotypes of peroxisome deficiency disorders. Hum Mol Genet 1998;7:20892094.

35. Braverman N, Steel G, Obie C, Moser A, Moser H, Gould SJ, Valle D. Human PEX7 encodes the peroxisomal PTS2 receptor and is responsible for rhizomelic chondrodysplasia punctata. Nat Genet 1997;15:369-376.

36. Motley AM, Hettema EH, Hogenhout EM, Brites P, ten Asbroek AL, Wijburg FA, Baas F, Heijmans HS, Tabak HF, Wanders RJA, Distel B. Rhizomelic chondrodysplasia punctata is a peroxisomal protein targeting disease caused by a non-functional PTS2 receptor. Nat Genet 1997;15:377-380.

37. Purdue PE, Zhang JW, Skoneczny M, Lazarow PB. Rhizomelic chondrodysplasia punctata is caused by deficiency of human PEX7, a homologue of the yeast PTS2 receptor. Nat Genet 1997;15:381-384.

38. Braverman N, Steel G, Lin P, Moser A, Moser H, Valle D. PEX7 gene structure, alternative transcripts, and evidence for a founder haplotype for the frequent RCDP allele, L292ter. Genomics 2000;63:181-192.

39. Warren DS, Morrell JC, Moser HW, Valle D, Gould SJ. Identification of PEX10, the gene defective in complementation group 7 of the peroxisome-biogenesis disorders. Am J Hum Genet 1998;63:347-359.

40. Okumoto K, Itoh R, Shimozawa N, Suzuki Y, Tamura S, Kondo N, Fujiki Y. Mutations in PEX10 is the cause of Zellweger peroxisome deficiency syndrome of complementation group B. Hum Mol Genet 1998;7:1399-1405.

41. Honsho M, Tamura S, Shimozawa N, Suzuki Y, Kondo N, Fujiki Y. Mutation in PEX16 is causal in the peroxisome-deficient Zellweger syndrome of complementation group D. Am J Hum Genet 1998;63:1622-1630.
42. Matsuzono Y, Kinoshita N, Tamura S, Shimozawa N, Hamasaki M, Ghaedi K, Wanders RJA, Suzuki Y, Kondo N, Fujiki Y. Human PEX19: cDNA cloning by functional complementation, mutation analysis in a patient with Zellweger syndrome, and potential role in peroxisomal membrane assembly. Proc Natl Acad Sci USA 1999;96: 2116-2121.

43. Sacksteder KA, Jones JM, South ST, Li X, Liu Y, Gould SJ. PEX19 binds multiple peroxisomal membrane proteins, is predominantly cytoplasmic, and is required for peroxisome membrane synthesis. J Cell Biol 2000;148:931-944.

44. Gloeckner CJ, Mayerhofer PU, Landgraf P, Muntau AC, Holzinger A, Gerber JK, Kammerer S, Adamski J, Roscher AA. Human adrenoleukodystrophy protein and related peroxisomal $\mathrm{ABC}$ transporters interact with the peroxisomal assembly protein PEX19p. Biochem Biophys Res Commun 2000;271:144-150.

45. Shimozawa N, Suzuki Y, Zhang Z, Imamura A, Toyama R, Mukai S, Fujiki Y, Tsukamoto T, Osumi T, Orii T, Wanders RJA, Kondo N. Nonsense and temperaturesensitive mutations in PEX13 are the cause of complementation group $\mathrm{H}$ of peroxisome biogenesis disorders. Hum Mol Genet 1999;8:1077-1083.

46. Gilzalsky W, Rehling P, Stein K, Kipper J, Blank L, Kunau WH, Erdmann R. Involvement of Pex13p in Pex14p localization and peroxisomal targeting signal 2-dependent protein import into peroxisomes. J Cell Biol 1999;144:1151-1162.

47. Poulos A, Christodoulou J, Chow CW, Goldblatt J, Paton BC, Orii T, Suzuki Y, Shimozawa N. Peroxisomal assembly defects: clinical, pathologic, and biochemical findings in two patients in a newly identified complementation group. J Pediatr 1995; 127:596-599.

48. Shimozawa N, Suzuki Y, Zhang Z, Imamura A, Ghaedi K, Fujiki Y, Kondo N. Identification of $P E X 3$ as the gene mutated in a Zellweger patient lacking peroxisomal remnant structure. Hum Mol Genet 2000;9:1995-1999.

49. Ghaedi K, Tamura S, Okumoto K, Matsuzono Y, Fujiki Y. The peroxin pex3p initiates membrane assembly in peroxisome biogenesis. Mol Biol Cell 2000;11:20852102.

50. Moser AB, Rasmussen M, Naidu S, Watkins PA, McGuinness M, Hajra AK, Chen G, Raymond G, Liu A, Gordon D, Gamaas K, Walton DS, Skjeldal OH, Guggenhelm MA, Jackson LG, Ellas ER, Moser HW. Phenotype of patients with peroxisomal disorders subdivided into sixteen complementation groups. J Pediatr 1995;127:1322.

51. Imamura A, Shimozawa N, Suzuki Y, Zhang Z, Tsukamoto T, Fujiki Y, Orii T, Osumi T, Wanders RJA, Kondo N. Temperature-sensitive mutation of PEX6 in peroxisome biogenesis disorders in complementation group C (CG-C): comparative study of PEX6 and PEX1. Pediatr Res 2000;48:541-545.

52. Watkins PA, McGuinness MC, Raymond GV, Hicks BA, Sisk JM, Moser AB, Moser HW. Distinction between peroxisomal bifunctional enzyme and acyl-CoA oxidase deficiencies. Ann Neurol 1995;38:472-477.

53. Hebestreit H, Wanders RJ, Schutgens RB, Espeel M, Kerckaert I, Roels F, Schmausser B, Schrod L, Marx A. Isolated dihydroxyacetonephosphate-acyl-transferase deficiency in rhizomelic chondrodysplasia punctata: clinical presentation, metabolic and histological findings. Eur J Pediatr 1996;155:1035-1039.

54. Martinez M, Pineda M, Vidal R, Conill J, Martin B. Docosahexaenoic acid -a new therapeutic approach to peroxisomal-disorder patients: experience with two cases. Neurology 1993;43:1389-1397.

55. Martinez M, Vazquez E. MRI evidence that docosahexaenoic acid ethyl ester improves myelination in generalized peroxisomal disorders. Neurology 1998;51:26-32.

56. Baes M, Gressens P, Baumgart E, Carmeliet P, Casteels M, Fransen M, Evrard P, Fahimi D, Declercq PE, Collen D, van Veldhoven PP, Mannaerts GP. A mouse model for Zellweger syndrome. Nat Genet 1997;17:49-57.

57. Faust PL, Hatten ME. Targeted deletion of the PEX2 peroxisome assembly gene in mice provides a model for Zellweger syndrome, a human neuronal migration disorder. J Cell Biol 1997;139:1293-1305. 